\title{
Pengembangan Modul Elektronik Berbantuan Aplikasi Flipping Book PDF Professional Pembelajaran Menulis Teks Eksplanasi
}

\section{Development of Electronic Modules Assisted by the Flipping Book PDF Professional Application for Learning to Write Explanatory Texts}

\author{
Yulia Marizal1,* dan Yasnur Asri² \\ 1,2 Magister Pendidikan Bahasa dan Sastra Indonesia, FBS, Universitas Negeri Padang \\ JI. Prof. Dr. Hamka, Air Tawar Barat, Kota Padang, Sumatera Barat, Indonesia \\ 1,* Email: marizalyulia14@gmail.com; Orcid: https://orcid.org/0000-0002-2618-0092 \\ 2 Email: yasnurasri5@gmail.com; Orcid: https://orcid.org/0000-0003-4057-081X
}

\begin{tabular}{|c|c|}
\hline $\begin{array}{l}\text { KEYWORDS } \\
\text { electronic module, flipping } \\
\text { book pdf professional, } \\
\text { explanatory text. } \\
\text { KATA KUNCI } \\
\text { modul elektronik, flipping } \\
\text { book pdf professional, teks } \\
\text { eksplanasi. }\end{array}$ & 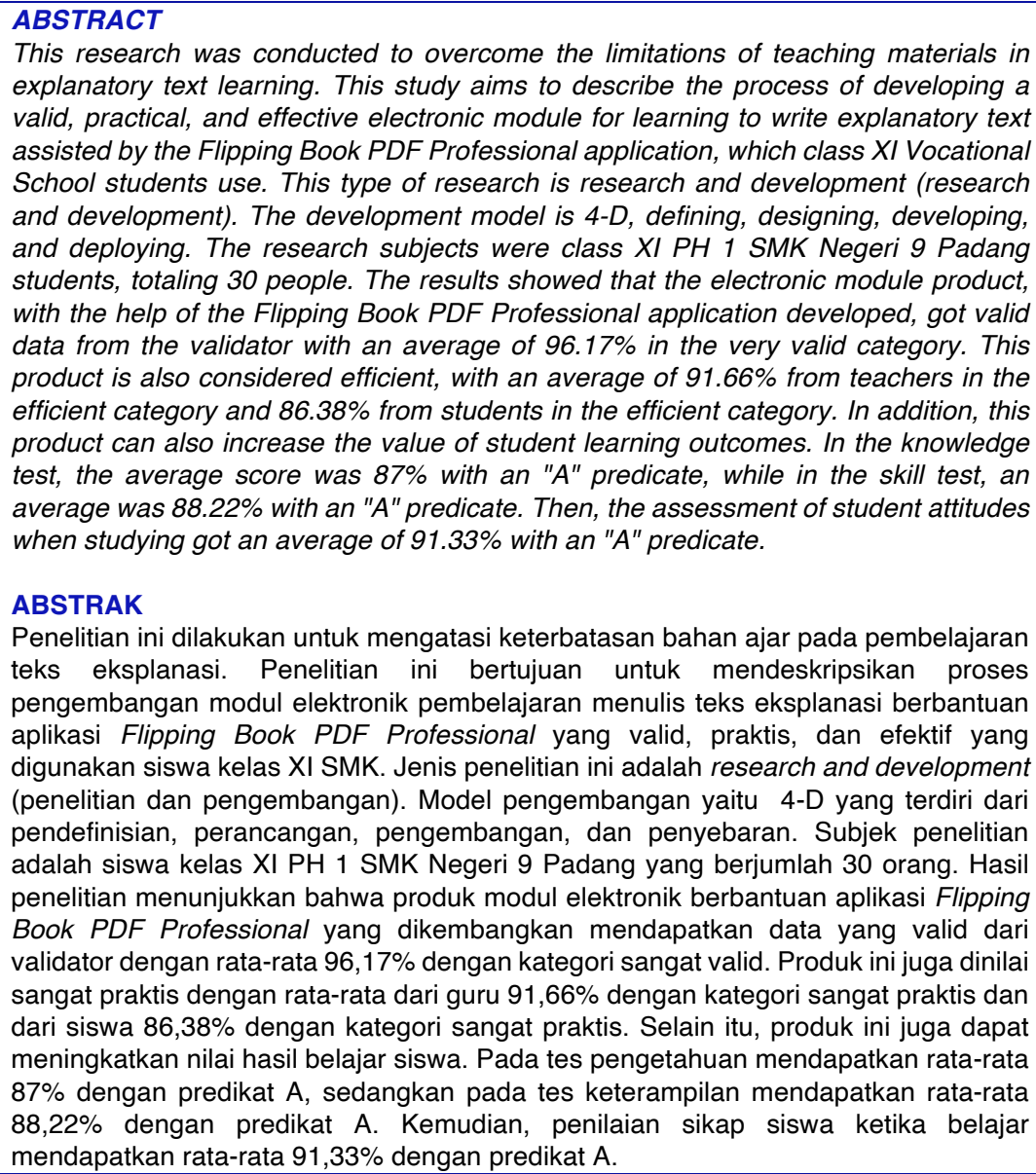 \\
\hline
\end{tabular}

To cite this article:

Marizal, Y. \& Asri, Y. (2022). Pengembangan Modul Elektronik Berbantuan Aplikasi Flipping Book PDF Professional Pembelajaran Menulis Teks Eksplanasi. Diglosia: Jurnal Kajian Bahasa, Sastra, dan Pengajarannya, 5(1), $135-152$. https://doi.org/10.30872/diglosia.v5i1.343 


\section{A. Pendahuluan}

Kegiatan pembelajaran dilakukan guna mendapatkan pengetahuan ataupun berbagi pengetahuan antara guru dan siswa yang saling berinteraksi di kelas. Kegiatan pembelajaran berjalan dengan baik apabila memanfaatkan sumber belajar, seperti media pembelajaran yang interaktif. Penggunaan media dalam belajar dapat memengaruhi proses pembelajaran di kelas. Media pembelajaran tersebut untuk meningkatkan proses pembelajaran dengan menggunakan modul pembelajaran secara efektif. Pemanfaatan media pembelajaran yang tepat akan mendukung dan berjalan secara terstruktur sehingga mempermudah siswa dalam melakukan kegiatan pembelajaran.

Media pembelajaran merupakan penyalur materi dan konsep pembelajaran dari guru kepada siswa ataupun sebagai alat penghubung siswa dan guru. Media pembelajaran diharapkan dapat membangkitkan pikiran, perasaan, minat serta perhatian siswa dalam proses pembelajaran. Sadiman et al. (2014, p. 7) menyebutkan bahwa media pembelajaran memungkinkan siswa sebagai peserta belajar yang mengamati suatu objek pembahasan yang sulit dijelaskan oleh guru, sehingga memanfaatkan media pembelajaran ini guna membuat pembelajaran yang bersifat abstrak menjadi mudah dipahami dan proses pembelajaran berjalan dengan efektif.

Seiring dengan pendapat tersebut, media pembelajaran akan lebih efektif ketika didorong oleh penggunaan modul pembelajaran yang tepat. Andi (2011) menyampaikan bahwa modul pembelajaran dapat dikatakan sebagai perangkat ajar yang disusun secara sistematis dan menggunakan bahasa yang mudah dipahami. Modul elektronik ini bisa digunakan secara mandiri, baik dengan bimbingan guru maupun tidak. Saat ini, sudah banyak peneliti mengembangkan modul elektronik. Modul elektronik ini berupa modul pembelajaran yang bisa diakses secara online atau offline melalui smartphone karena modul ini disajikan secara digital (Suyoso \& Nurohman, 2014, p. 74).

Melalui modul elektronik ini, berharap siswa mampu mencapai tujuan kompetensi dasar yang diinginkan. Modul elektronik ini memaparkan teks, gambar, animasi, dan video pembelajaran serta dapat mengurangi penggunaan kertas dalam proses belajar mengajar. Penyajian perangkat ajar dalam bentuk elektronik atau digital ini pastinya akan lebih efektif dan menarik. Pada akhirnya, keberadaan modul elektronik dapat menunjang pembelajaran dengan membantu peranan guru sebagai sumber utama bagi pengetahuan siswa. Tak hanya itu, modul dalam bentuk elektronik ini dianggap sebagai bahan ajar alternatif yang efisien dan efektif, serta interaktif guna meningkatkan semangat siswa dan hasil belajar siswa. Putra et al., (2014, p. 2) juga menyampaikan bahwa penggunaan bahan ajar yang valid, praktis, dan efektif dapat membantu guru untuk bisa mencapai tujuan pembelajaran.

Ada beberapa peneliti yang melakukan penelitian mengenai modul elektronik pada bidang pendidikan di berbagai negara seperti Jepang, Taiwan, Malaysia, Iran, USA, dan Thailand. Mouri et al., (2018) dari Jepang mengemukakan bahwa modul elektronik dalam pembelajaran berbasis tugas yang disebut Learning Log Navigator dapat meningkatkan pengalaman belajar siswa. Sejalan dengan itu, 
Lin \& Lin (2019) di Taiwan juga mengatakan bahwa modul elektronik digunakan untuk memberikan pengajaran remedial pada siswa kelas VIII yang mempunyai prestasi akademik rendah. Modul elektronik dapat menghasilkan kinerja ujian siswa menjadi lebih bagus dan meningkatkan pengalaman belajar siswa. Tak hanya itu, Noor et al., (2012) di Malaysia juga menyatakan bahwa dalam penggunaan modul elektronik memudahkan guru dalam manajemen kelas dan pemantauan kegiatan masing-masing siswa.

Kemudian, Sirikham \& Sae-Ear (2014) dari Thailand juga mengemukakan efek menggunakan modul elektronik terbagi dua, yaitu (1) efek menggunakan modul elektronik dalam instruksi pada perhatian siswa, dan (2) efek menggunakan modul elektronik dalam instruksi tentang perilaku belajar siswa. Sama halnya dengan Jones \& Brown (2011) di Iran yang juga menyampaikan bahwa penggunaan sumber daya elektronik menyebabkan perbedaan yang berarti akan dibuat dalam beberapa konteks seperti kemajuan akademik, berbagai sumber belajar, fleksibilitas sambil belajar, dan efektivitas belajar antara siswa program virtual dan konvensional

Di Indonesia, penelitian mengenai modul elektronik juga dilakukan oleh beberapa peneliti. Purwaningtyas et al., (2017) juga berpendapat bahwa modul elektronik disebut sebagai perangkat ajar yang cocok dengan ciri khas materi ajar yang akan dikemas agar menjadi satu kesatuan yang utuh secara sistematis yang mengandung fitur multimedia yang tidak dapat ditemukan dalam modul cetak sehingga pembelajaran terasa berinovasi dan tidak membosankan. Sama halnya dengan Krisnayuni et al. (2015) juga menyampaikan bahwa di dalam modul elektronik juga dapat menyisipkan animasi, audio, ataupun video yang dapat membuat siswa menjadi semangat sehingga meningkatkan keterlibatan siswa dalam pembelajaran. Kemudian, Priatna et al. (2017) mengatakan bahwa modul elektronik mendapatkan penilaian yang positif karena proses kegiatan pembelajaran memiliki kemudahan bagi siswa. Selain itu, pengoperasian modul elektronik ini hanya dengan membuka file yang sudah dibagikan, maka siswa dapat mengakses modul elektronik dengan mudah.

Tak hanya itu, Oktavia (2021) berpendapat bahwa modul elektronik bahasa Indonesia yang diciptakannya dapat membuat pembelajaran yang kreatif, aktif, dan menarik minat siswa untuk belajar sehingga hasil penelitiannya mendapatkan rata-rata $94,46 \%$ dengan kriteria sangat praktis. Sejalan dengan itu, Yuswanti (2020) juga menyampaikan bahwa modul elektronik menulis teks eksplanasi yang ditelitinya mendapatkan hasil $82 \%$ dengan kriteria sangat layak karena mampu menumbuhkan rasa semangat siswa dalam belajar.

Modul elektronik ini berupa bahan ajar yang dilengkapi dengan materi pembelajaran. Salah satu teks yang dipelajari di semester satu kelas XI SMA/SMK adalah teks eksplanasi. Teks eksplanasi yaitu materi yang sederhana dan dekat di kehidupan sehari-hari siswa karena berhubungan dengan fenomena alam dan sosial. Waluyo (2014, p. 125) mengatakan bahwa teks eksplanasi bertujuan untuk menjelaskan bagaimana sebuah peristiwa itu berlangsung. Sedangkan, Priyatni (2014, p. 162) menyebutkan bahwa teks eksplanasi menjelaskan proses yang berhubungan dengan fenomena alam, sosial, dan budaya. Jadi, dengan menulis siswa dapat mengasah keterampilan menulisnya 
dan juga mengembangkan kemampuan berpikir kritis dalam belajar (Rahmah \& Widyartono, 2021, p. 474). Materi teks eksplanasi dalam kurikulum 2013 terdapat di Kompetensi Inti (KI-3) dan (KI-4), kemudian juga terdapat di Kompetensi Dasar (KD 3.2) dan (KD 4.2). Rumusan (KD 3.2) adalah "menganalisis struktur dan unsur kebahasaan teks eksplanasi" dan rumusan (KD 4.2) adalah "memproduksi teks eksplanasi secara lisan atau tulis dengan memperhatikan struktur dan unsur kebahasaan".

Berdasarkan hasil wawancara yang dilaksanakan pada siswa dan guru di kelas XI SMK Negeri 9 Padang, siswa lebih banyak mencari informasi tambahan dalam menyelesaikan tugas di internet sehingga bahasa yang digunakan menjadi tidak baku, penyusunan kata dalam kalimat tidak sesuai, dan penulisan tata bahasa yang kurang benar. Apalagi dimasa pandemi sekarang ini semakin menyulitkan guru dalam memberikan materi pembelajaran sehingga dalam memanfaatkan media pembelajaran tidak maksimal sebagai sarana untuk membantu dalam menyampaikan materi pembelajaran. Selain itu, penggunaan modul elektronik pun tidak pernah dilakukan di sekolah ini. Siswa hanya menggunakan buku paket dari pemerintah. Dengan belajar dari rumah, siswa hendaknya diberi bahan ajar yang inovatif sehingga pembelajaran dari rumah juga semangat.

Masalah mengenai modul elektronik pembelajaran ini juga dilihat dari hasil belajar menulis teks eksplanasi siswa. Ada beberapa masalah yang ditemui siswa dalam menulis teks eksplanasi, yaitu (1) fakta di lapangan menunjukkan bahwa nilai keterampilan menulis teks eksplanasi siswa masih di bawah ratarata, (2) tidak semua siswa aktif dalam proses pembelajaran, (3) siswa ketika menulis teks eksplanasi sering terkendala dalam menentukan struktur kebahasaan dan ciri kebahasaan teks, (3) siswa meminta waktu tambahan karena tidak dapat menyelesaikan tugas tepat waktu dan nilai yang diperoleh pun di bawah KKM, dan (4) kurangnya bahan ajar yang mendukung pembelajaran menulis teks eksplanasi karena hanya memakai satu buku saja. Dengan demikian, penggunaan modul elektronik ini dapat mengurangi masalah siswa dalam menulis teks eksplanasi.

Modul elektronik sangat dianjurkan untuk dipergunakan dalam meningkatkan keaktifan siswa dalam belajar. Tidak hanya itu, modul elektronik juga bertujuan untuk meningkatkan kemandirian siswa dalam belajar (Munthe et al., 2019). Sama halnya dengan pendapat tersebut, Yulianti (2017) juga mengatakan bahwa modul elektronik mampu meningkatkan hasil belajar kognitif siswa. Modul elektronik dapat diterapkan sebagai sumber belajar mandiri siswa guna meningkatkan pemahaman siswa, serta tidak tergantung dengan satu sumber belajar saja. Saat ini, buku elektronik ditampilkan dalam bentuk flipbook. Sugianto et al., (2013, p. 102) berpendapat bahwa flipbook dapat meningkatkan pemahaman dan pencapaian belajar siswa. Salah satu software pembuat buku elektronik dalam bentuk flipbook adalah Flipping Book PDF Professional.

Flipping Book PDF Professional adalah aplikasi yang digunakan membuat layout dokumen (Microsoft Word), kemudian dikonversikan menjadi file PDF, lalu memasukkannya menjadi dokumen eBook yang siap digunakan (Watin \& Kustijono, 2017). Flipping Book PDF Professional ini sangat mudah digunakan 
dalam pembelajaran dan pengoperasiannya mudah sehingga tidak perlu kemahiran karena hanya dengan mengklik link tautannya saja. Selain itu, dengan menggunakan Flipping Book PDF Professional juga mengutamakan penyajian materi pembelajaran berupa gambar, video, ataupun audio sehingga mempermudah guru dalam pembuatan modul elektronik (Seruni et al., 2019). Format yang disediakan dalam Flipping Book PDF Professional berupa EXE, APP, FBR, dan HTML. Guru bisa memilih sesuai dengan kapasitas yang diinginkan. Penggunaan media pembelajaran berupa Flipping Book PDF Professional ini memberikan hasil yang berbeda dari media pembelajaran konvensional karena Flipping Book PDF Professional lebih unggul untuk lebih meningkatkan rasa keingintahuan siswa dalam memahami materi pembelajaran (Searmadi, 2016, p. 47). Alasan lebih memilih aplikasi Flipping Book PDF Professional dibandingkan aplikasi lainnya karena memiliki beberapa keunggulan yaitu (1) sangat mudah pembuatan media pembelajaran, (2) dapat digunakan untuk merancang bahan ajar bagi siswa, (3) pengoperasiannya sangat mudah, (4) menyajikan dalam bentuk efek flip, yaitu membalik lembar halaman sehingga seperti membaca buku sungguhan yang dilengkapi dengan video, gambar, dan audio, (5) dapat diterbitkan secara online ataupun offline, dan (6) menciptakan media pembelajaran yang inovatif dan menyenangkan.

Temuan lainnya yang melakukan penelitian mengenai modul elektronik berbantuan aplikasi adalah Asmi et al. (2018) yang mengemukakan bahwa dengan menggunakan modul elektronik bisa menjadi pemecahan kebutuhan bahan ajar yang inovatif dan juga memberikan semangat baru bagi mahasiswa. Selanjutnya, penelitian yang dilakukan oleh Nisa et al., (2020) yang mengatakan bahwa modul elektronik ini sangat baik digunakan sebab menjadi salah satu inovatif terbaru yang digunakan di masa pandemi.

Jadi, dalam pembelajaran daring saat ini sangat diperlukan bahan ajar yang menunjang pembelajaran dari rumah sehingga mampu memberikan dampak yang lebih baik dan memudahkan guru dan siswa dalam kegiatan pembelajaran. Berdasarkan uraian tersebut, peneliti merasa perlu untuk mengembangkan modul elektronik berbantuan aplikasi Flipping Book PDF Professional yang valid, praktis, dan efektif dalam pembelajaran menulis teks eksplanasi SMK Negeri 9 Padang. Oleh karena itu, maka penelitian ini bertujuan untuk menghasilkan sebuah produk dengan melihat kevalidan, kepraktisan, dan keefektifan produk dalam pembelajaran.

\section{B. Metode}

Jenis penelitian ini merujuk pada pendapat Sugiyono (2010), yaitu research and development (penelitian pengembangan). Penelitian pengembangan adalah metode penelitian yang digunakan untuk menghasilkan produk tertentu dan menguji keefektifan produk tersebut. Penelitian ini akan mengembangkan modul elektronik berbantuan aplikasi Flipping Book PDF Professional pembelajaran menulis teks eksplanasi. Model pengembangan yang diterapkan adalah model 4-D yang disarankan oleh Thiagarajan \& Semmel (dalam Trianto, 2009). Model 4-D terdiri atas empat tahap, yaitu pendefinisian (define), perancangan (design), 
pengembangan (develop), dan penyebaran (disseminate). Uji coba produk dilaksanakan untuk melihat tingkat keterpakaian dan keterlaksanaan modul elektronik yang dirancang. Dalam hal ini, dilakukan uji coba terbatas di kelas berdasarkan jenis teks yang dipelajari. Subjek uji coba produk adalah siswa kelas XI PH 1 SMK Negeri 9 Padang yang berjumlah 30 orang. Penelitian ini dibatasi di SMK yang telah menggunakan kurikulum 2013.

Data yang dihasilkan dari uji coba berupa data kualitatif dan data kuantitatif. Data kualitatif dilihat dari hasil wawancara pada tahap pendefinisian, sedangkan data kuantitatif berdasarkan hasil pengolahan angket yang diberikan kepada validator, guru, siswa, dan hasil belajar siswa. Prosedur penelitian pengembangan yang dilakukan sesuai dengan alur pada Gambar 1 .

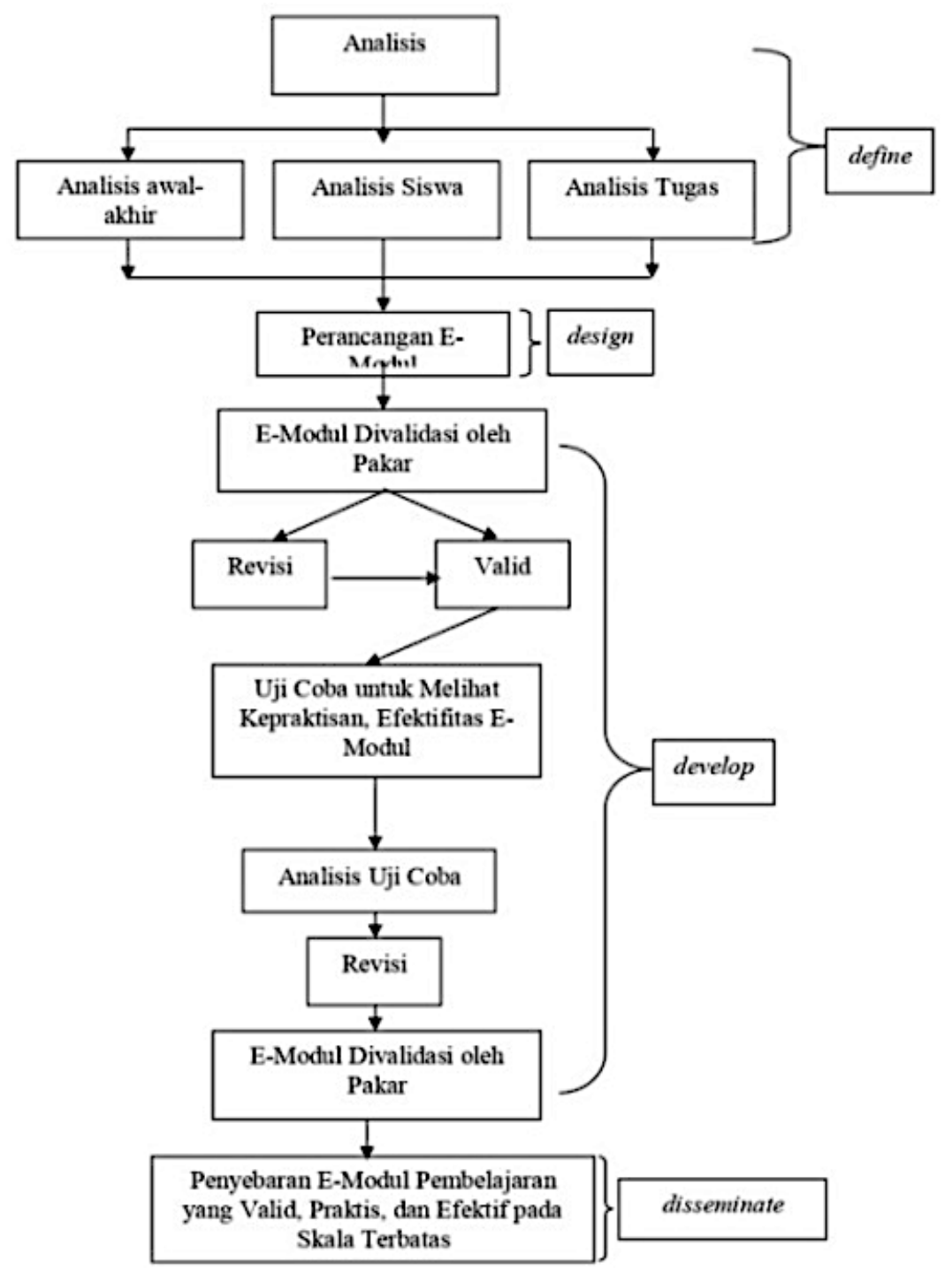

Gambar 1. Prosedur Penelitian Pengembangan 
Tabel 1. Skala Empat

\begin{tabular}{cll}
\hline No. & Tingkat pencapaian & Kategori \\
\hline 1. & $81-100$ & Sangat Baik \\
2. & $61-80$ & Baik \\
3. & $41-60$ & Cukup Baik \\
4. & $21-40$ & Kurang Baik \\
5. & $0-20$ & Tidak Baik \\
\hline
\end{tabular}

(dimodifikasi dari Riduwan, 2012)

Instrumen penelitian ini terdiri atas sepuluh angket penelitian, yaitu (1) lembar wawancara, (2) angket analisis siswa, (3) angket analisis kurikulum, (4) angket analisis konsep, (5) lembar validasi produk, (6) lembar praktikalitas modul elektronik, (7) lembar observasi aktivitas siswa, (8) tes kinerja menulis, (9) rubrik penilaian tes kinerja menulis, dan (10) angket penyebaran modul elektronik. Teknik analisis data terdiri atas empat yaitu analisis tahap pendefinisian, analisis validitas modul elektronik, analisis praktikalitas modul elektronik, analisis efektivitas modul elektronik. Untuk melihat hasil pengolahan data, maka digunakan skala empat sebagai acuan pengubahan skor menjadi nilai sebagaimana Tabel 1.

Berdasarkan Tabel 1, tingkat pencapaian dari 81-100 masuk pada kategori Sangat Baik, tingkat pencapaian dari 61-80 masuk pada kategori Baik, tingkat pencapaian dari 41-60 masuk pada kategori Cukup Baik, pencapaian 21-40 masuk pada kategori Kurang Baik, dan tingkat pencapaian dari 0-20 masuk pada kategori Tidak Baik. Penggunaan skala empat ini untuk mempermudah peneliti dalam mengubah skor menjadi nilai dan nilai menjadi kategori sesuai dengan ketentuannya.

\section{Pembahasan}

Proses pengembangan modul elektronik dilaksanakan mengikuti model 4-D yang disarankan oleh Thiagarajan \& Semmel (dalam Trianto, 2009). Model 4-D ini terdiri atas empat tahapan pengembangan, yaitu pendefinisian (define), perancangan (design), pengembangan (develop), dan penyebaran (disseminate). Bagian ini memaparkan hasil penelitian dari tiga tahapan saja, yaitu tahap pendefinisian, tahap perancangan, dan tahap pengembangan.

\section{Tahap Pendefinisian}

Pada tahap pendefinisian, ada lima tahapan yaitu analisis awal akhir, analisis mahasiswa, analisis materi, analisis tugas, dan spesifikasi tujuan pembelajaran (Kurniawan \& Dewi, 2017, p. 216). Akan tetapi, pada penelitian ini, tahapan pendefinisian terhadap pengembangan modul elektronik pembelajaran merujuk pada pendapat Trianto (2012) yang menjelaskan tiga tahapan, yaitu analisis awal akhir, analisis siswa, dan analisis konsep. 


\section{a. Analisis Awal Akhir}

Analisis awal akhir dilakukan untuk memperoleh informasi tentang kondisi pembelajaran siswa. Wawancara dilakukan dengan guru mata pelajaran Bahasa Indonesia, yaitu Ibu Erni Yusnita, S.Pd. Hasil wawancara ini akan dianalisis guna mendapatkan pokok masalah yang ada dalam kegiatan pembelajaran bahasa Indonesia, terkhusus menulis teks eksplanasi. Berdasarkan hasil analisis awal akhir, dapat dijelaskan keterangan sebagai berikut.

Pertama, situasi pembelajaran menulis teks eksplanasi. Selama ini pembelajaran terjadi dengan guru sebagai pusat pembelajaran, sehingga dominasi guru membuat siswa tidak aktif dan masih banyak mencontek karya orang lain, baik dari teman, internet, ataupun buku. Siswa juga tidak disiplin dalam mengerjakan tugas. Peristiwa ini dilihat dari banyaknya siswa yang meminta waktu tambahan sehingga siswa mendapatkan nilai di bawah rata-rata batas minimal. Kedua, sumber belajar siswa hanya buku paket dari pemerintah. Buku ini wajib ada dalam proses pembelajaran. Siswa juga disarankan mencari sumber lain, seperti dari internet, tetapi siswa masih sulit membedakan keabsahan sumber tersebut. Ketiga, guru tidak membuat bahan ajar sendiri. Di samping itu, guru mempunyai keterbatasan waktu dan referensi untuk menyusun bahan ajar, ditambah dengan beban mengajar yang banyak. Keempat, bukubuku yang tersedia di perpustakaan belum banyak yang berkaitan dengan teks eksplanasi. Buku yang menjelaskan materi tentang teks eksplanasi belum ada tersedia di perpustakaan tersebut. Kelima, pendekatan pembelajaran berpedoman pada penyusunan rencana pelaksanaan pembelajaran (RPP). RPP tersebut dikembangkan berdasarkan pendekatan yang ditetapkan kurikulum yang digunakan yaitu kurikulum 2013 adalah pendekatan saintifik. Untuk proses pembelajaran, guru mengikuti proses yang terdapat dalam buku paket.

\section{b. Analisis Siswa}

Analisis siswa dilakukan untuk menelaah karakteristik siswa dalam belajar. Secara spesifik, analisis siswa yang dimaksudkan untuk mengumpulkan informasi yang berkaitan dengan situasi pembelajaran yang dibutuhkan. Pengumpulan informasi ini dilakukan dengan menyebarkan angket analisis siswa. Angket tersebut diisi sesuai dengan kondisi siswa yang sebenarnya. Dalam hal ini, subjek uji coba adalah siswa kelas XI PH 1 SMK Negeri 9 Padang. Analisis karakteristik siswa dilakukan untuk mengidentifikasi jenis kelamin, usia, dan tingkat kedewasaan siswa kelas XI PH 1 SMK Negeri 9 Padang. Jumlah siswa ini adalah 30 orang, yaitu 14 siswa laki-laki dan 16 siswa perempuan. Usia siswa pada kelas ini antara 17-18 tahun.

\section{c. Analisis Konsep}

Analisis konsep merupakan analisis kurikulum yang digunakan dalam mengembangkan modul elektronik yaitu kurikulum 2013. Sesuai dengan Permendikbud Nomor 58 Tahun 2014 tentang kerangka dasar dan struktur 
kurikulum SMK, struktur Kurikulum 2013 terdiri atas Kompetensi Inti (KI) dan Kompetensi Dasar (KD). Kompetensi Inti (KI) Sekolah Menengah Kejuruan (SMK) merupakan tingkat kemampuan untuk mencapai Standar Kompetensi Lulusan (SKL) yang harus dimiliki siswa SMK pada setiap tingkat kelas. Rumusan Kompetensi Inti (KI), Kompetensi Dasar (KD) dan Indikator Pencapaian dalam pembelajaran menulis teks eksplanasi dapat dilihat pada Tabel 2.

Tabel 2. Kompetensi Inti, Kompetensi Dasar, dan Indikator Pencapaian

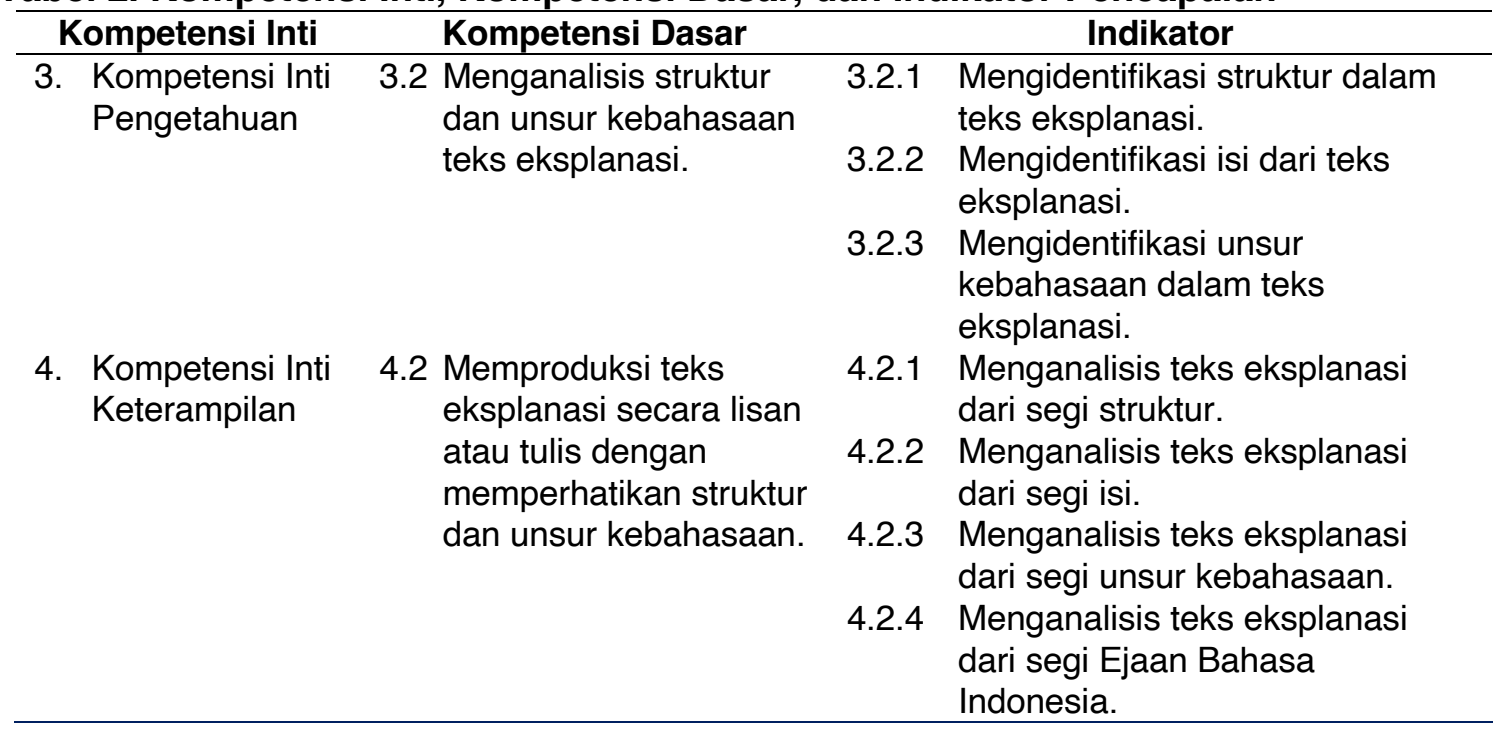

Berdasarkan Tabel 2, produk pengembangan yang akan dihasilkan berlandaskan pada konsep KI, KD, dan Indikator Pencapaian Pembelajaran agar proses pembelajaran terstruktur dan terarah sesuai dengan Kurikulum 2013.

\section{Tahap Perancangan}

Modul elektronik yang dirancang harus menarik dan menggunakan bahasa yang komunikatif. Selain itu, modul elektronik juga dilengkapi dengan soal-soal yang dapat dikerjakan secara individu ataupun kelompok (Lasmiyati \& Harta, 2014). Sejalan dengan itu, Hasanah (2015) juga berpendapat bahwa bahan ajar yang baik harus mampu merumuskan tujuan pembelajaran secara maksimal dan tersusun secara sistematika dengan penyajian yang mengandung materi dan contoh yang jelas, serta langkah-langkaj yang mudah diikuti oleh siswa. Penyusunan kerangka modul elektronik dibantu dengan aplikasi Flipping Book PDF Professional. Modul elektronik yang dirancang berdasarkan teori tentang struktur modul elektronik, yaitu bagian pendahuluan, kegiatan belajar, dan evaluasi. Kegiatan pembelajaran ada dua bagian, yaitu (a) kegiatan pembelajaran 1 yang mengacu pada KD 3.2 dan (b) kegiatan pembelajaran 2 yang mengacu KD 4.2. Rancangan modul elektronik berbantuan aplikasi Flipping Book PDF Professional yang dikembangkan dapat dilihat pada Tabel 3, Gambar 2, dan Gambar 3. 
Tabel 3. Kerangka Modul Elektronik Berbantuan Aplikasi Flipping Book PDF Professional Pembelajaran Menulis Teks Eksplanasi

Kerangka Pendahuluan
1. Kompetensi Inti
2. Kompetensi Dasar
3. Orientasi
4. Prasyarat
5. Petunjuk Penggunaan dan
waktu
Isi Kerangka Pendahuluan

Kompetensi inti sebagai acuan dalam menyusun isi modul elektronik.

Kompetensi dasar sebagai acuan dalam menyusun isi modul elektronik.

Pemaparan pokok-pokok penting yang dipelajari oleh siswa.

Syarat yang harus dipenuhi sebelum mempelajari modul elektronik. waktu

Panduan cara menggunakan modul elektronik untuk siswa dan jumlah waktu yang dibutuhkan untuk mempelajari modul elektronik.

\begin{tabular}{|c|c|}
\hline $\begin{array}{l}\text { Kerangka Kegiatan } \\
\text { Pembelajaran }\end{array}$ & Isi Kerangka Kegiatan Pembelajaran \\
\hline 1. Kompetensi Dasar & $\begin{array}{l}\text { Kompetensi dasar sebagai acuan untuk menyusun isi } \\
\text { modul elektronik. }\end{array}$ \\
\hline 2. Indikator & Kompetensi yang akan dicapai siswa setiap pembelajaran. \\
\hline 3. Tujuan pembelajaran & $\begin{array}{l}\text { Pernyataan yang ingin dicapai siswa dalam kegiatan } \\
\text { belajar. }\end{array}$ \\
\hline 4. Manfaat kegiatan belajar & Manfaat yang diperoleh siswa setiap kegiatan belajar. \\
\hline 5. Uraian materi & Materi yang berkaitan dengan indikator. \\
\hline 6. Rangkuman & Kesimpulan dari kegiatan pembelajaran 1. \\
\hline 7. Latihan & $\begin{array}{l}\text { Pertanyaan guna memberikan penguatan pemahaman } \\
\text { mengenai konsep yang baru dipelajari. }\end{array}$ \\
\hline 8. Penilaian Diri & $\begin{array}{l}\text { Penilaian sikap dan perilaku siswa untuk mengukur } \\
\text { kelebihan dan kekurangan dalam mencapai tujuan } \\
\text { pembelajaran. }\end{array}$ \\
\hline 9. Informasi pendukung & Berisi informasi tambahan bagi siswa. \\
\hline Kerangka Evaluasi & Isi Kerangka Evaluasi E-Modul \\
\hline 1. Tes unjuk kerja & $\begin{array}{l}\text { Berisi petunjuk mengerjakan tes yang akan ditulis siswa } \\
\text { yaitu menulis teks eksplanasi. }\end{array}$ \\
\hline $\begin{array}{l}\text { 2. Rubrik penilaian Tes unjuk } \\
\text { kerja }\end{array}$ & $\begin{array}{l}\text { Tabel yang berisi aspek yang dinilai, bobot, dan tingkat } \\
\text { kinerja, dan deskripsi tingkat perolehan skor. }\end{array}$ \\
\hline $\begin{array}{l}\text { 3. Lembar jawaban tes unjuk } \\
\text { kerja }\end{array}$ & $\begin{array}{l}\text { Link yang digunakan untuk terhubung ke akun google } \\
\text { siswa. }\end{array}$ \\
\hline $\begin{array}{l}\text { 4. Panduan penilaian hasil } \\
\text { tes unjuk kerja }\end{array}$ & $\begin{array}{l}\text { Berisi cara yang dapat digunakan untuk menghitung skor } \\
\text { menjadi nilai, rumus yang digunakan, dan tabel penilaian } \\
\text { acuan patokan. }\end{array}$ \\
\hline
\end{tabular}

Kemudian, menyusun unsur-unsur pendukung modul elektronik. Unsur pendukung tersebut terdiri atas sampul modul elektronik, bagan uraian isi modul elektronik, kata pengantar, daftar isi, petunjuk penggunaan modul elektronik, daftar rujukan, glosarium, dan sebagainya. 


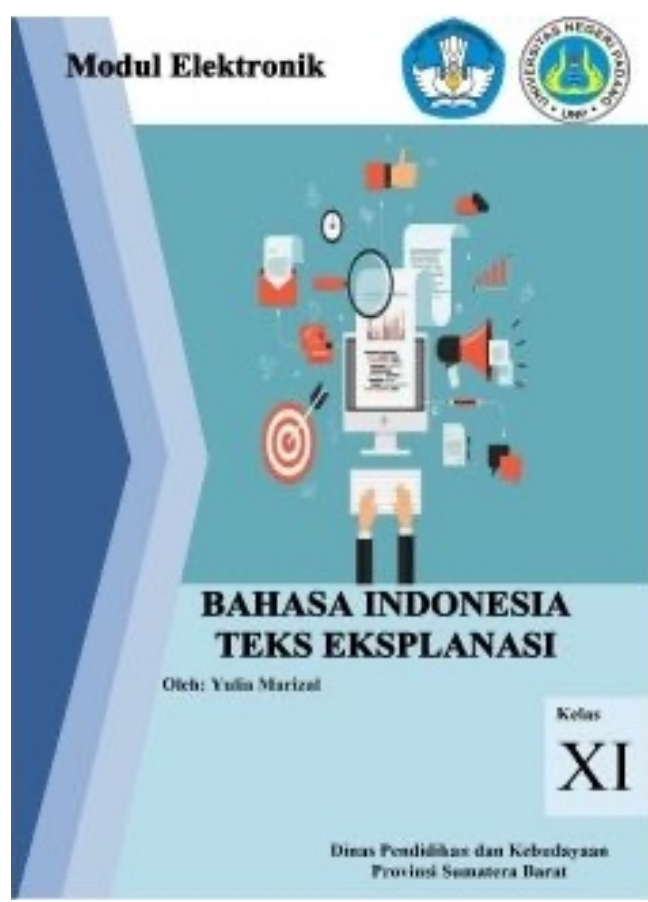

(a)

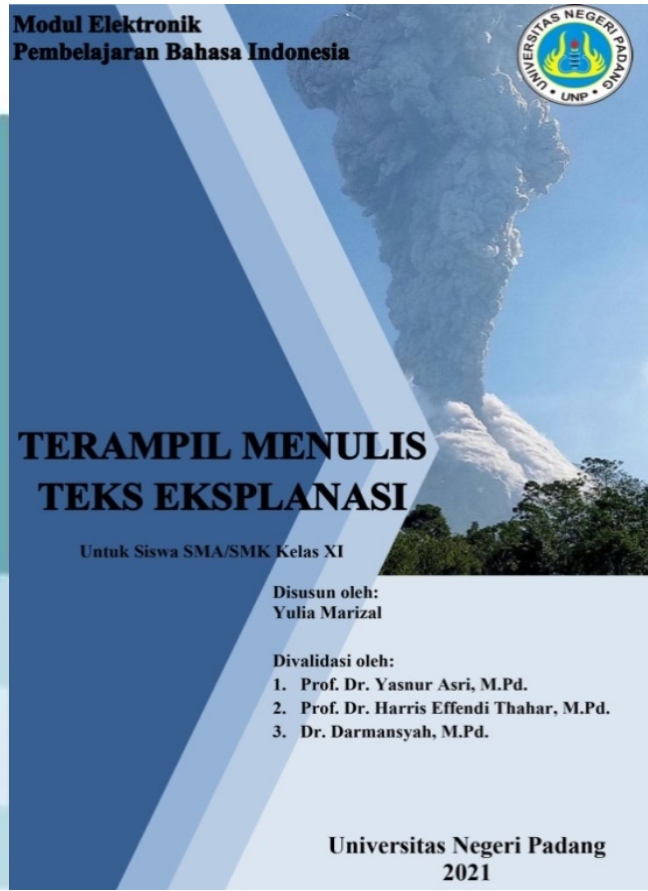

(b)

Gambar 2. Sampul Depan (a) dan Sampul Dalam (b) Modul Elektronik Menulis Teks Eksplanasi

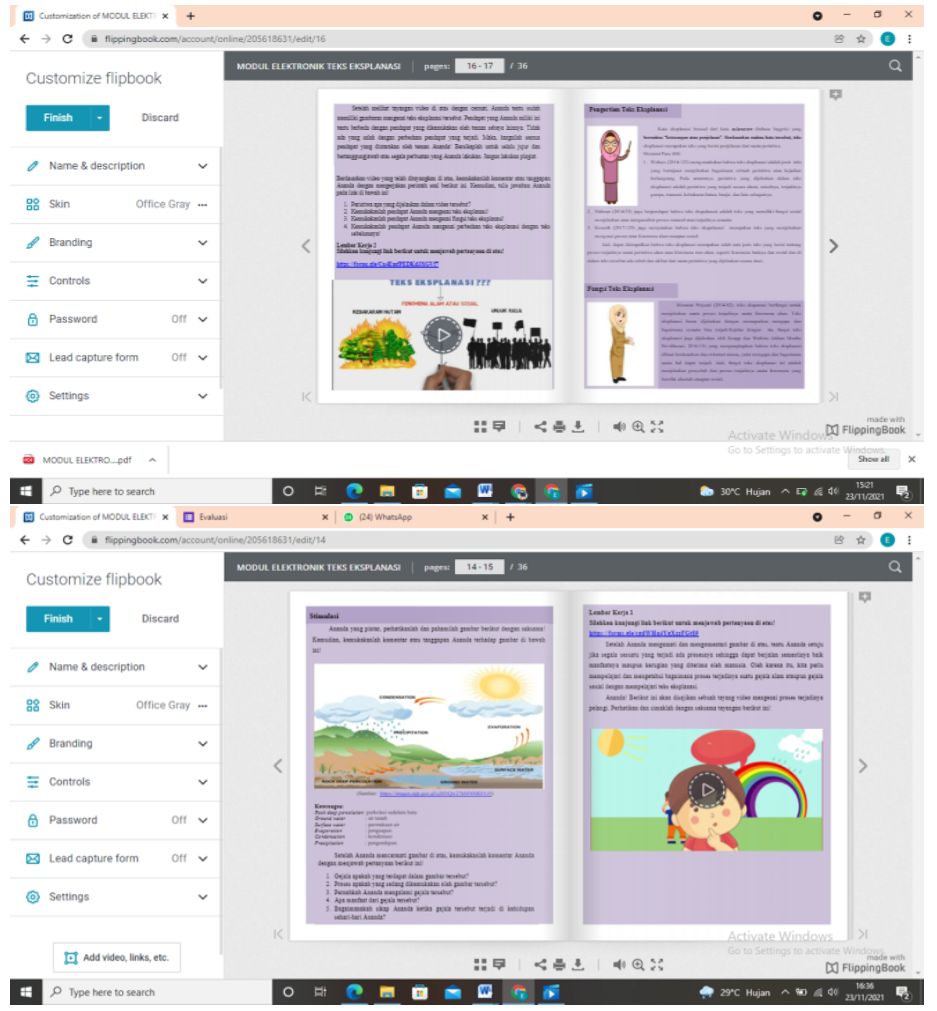

Gambar 3. Uraian Materi dan Lembar Kerja Kegiatan Pembelajaran 


\section{Tahap Pengembangan}

Kegiatan ini terdiri atas tiga tahap, yaitu (a) uji validitas, (b) uji praktikalitas, dan (c) uji efektivitas. Ketiga tahap ini dilakukan secara berurutan. Uji validitas dinilai berdasarkan tingkat kevalidan modul elektronik yang telah dirancang. Proses validasi ini dilakukan oleh pakar yang ahli di bidangnya. Berdasarkan hasil validasi tersebut, modul elektronik apakah valid atau tidak, atau layak untuk diujicobakan atau tidak kepada siswa di kelas.

Setelah modul elektronik dinyatakan valid, selanjutnya di uji praktikalitas modul elektronik tersebu. Uji praktikalitas dilakukan ketika uji coba modul elektronik yang sudah dinyatakan valid. Uji coba ini dilakukan agar dapat melihat kepraktisan dan efektivitas modul elektronik. Uji praktikalitas diperoleh dari guru, siswa, dan pengamatan aktivitas belajar selama menggunakan modul elektronik pembelajaran, sedangkan uji efektivitas modul elektronik diperoleh dari hasil belajar (kognitif dan psikomotor), setelah mempelajari modul elektronik, selanjutnya efektivitas modul elektronik diperoleh dari nilai sikap siswa selama mempelajari modul elektronik. Untuk lebih jelasnya, tahap pengembangan ini dipaparkan sebagai berikut.

\section{a. Validitas Modul Elektronik}

Uji validasi merupakan proses penilaian rancangan produk yang dilakukan dengan memberikan penilaian berdasarkan pemikiran yang rasional (Emzir, 2010, p. 273). Selain itu, modul yang berkualitas juga memperhatikan komponen yang ditetapkan oleh Badan Standar Nasional Pendidikan (BNSP), yaitu kelayakan isi, bahasa dan gambar, penyajian, dan kegrafikaan (Lasmiyati \& Harta, 2014). Modul elektronik ini divalidasi oleh dua pakar ahli, yaitu satu orang dosen Bahasa dan Sastra Indonesia dan satu orang dosen Teknologi Pendidikan. Ada beberapa aspek validasi oleh validator, yaitu kelayakan isi, kelayakan kebahasaan, kelayakan penyajian, dan kelayakan kegrafikaan. Lembar validasi yang diisi setiap validator sesuai dengan bidang dan keahliannya masing-masing. Validator memvalidasi modul elektronik terdiri atas dua pakar ahli. Pertama, Prof. Dr. Harris Effendi Thahar, M.Pd. dari Jurusan Pendidikan Bahasa dan Sastra Indonesia yang memvalidasi modul elektronik dari segi isi, kebahasaan, penyajian, dan kegrafikaan. Kedua, Dr. Darmansyah, M.Pd. dari Jurusan Teknologi Pendidikan yang memvalidasi modul elektronik dari segi penyajian dan kegrafikaan.

Proses validasi dilakukan dengan cara mengisi lembar validasi. Secara keseluruhan, lembar validasi terdiri atas butir pernyataan dengan pembagian 19 butir pernyataan untuk kelayakan isi, 8 butir pernyataan untuk kebahasaan, 20 butir untuk penyajian, dan 14 butir pernyataan untuk kegrafikaan. 
Tabel 4. Hasil Validasi Modul Elektronik oleh Pakar Ahli

\begin{tabular}{clccc}
\hline No. & \multicolumn{1}{c}{ Aspek yang Dinilai } & $\begin{array}{c}\text { Perolehan } \\
\text { Skor }\end{array}$ & Validitas & Kategori \\
\hline 1. & Kelayakan isi modul elektronik & 73 & $96,05 \%$ & Sangat valid \\
2. & Kebahasaan modul elektronik & 32 & $100 \%$ & Sangat valid \\
3. & Penyaiian modul elektronik & 98,5 & $98,5 \%$ & Sangat valid \\
4. & Kegrafikaan modul elektronik & 50,5 & $90,17 \%$ & Sangat valid \\
\hline Total & $\mathbf{2 5 4}$ & $\mathbf{9 6 , 1 7 \%}$ & Sangat valid \\
\hline
\end{tabular}

Berdasarkan Tabel 4, hasil validasi modul elektronik dengan dua validator, yaitu (1) kelayakan isi modul elektronik memperoleh persentase $96,05 \%$ dengan kategori sangat valid, (2) kebahasaan modul elektronik memperoleh persentase $100 \%$ dengan kategori sangat valid, (3) penyajian modul elektronik memperoleh persentase $98,5 \%$ dengan kategori sangat valid, dan (4) kegrafikaan modul elektronik memperoleh persentase 90,17\% dengan kategori sangat valid. Jadi, secara keseluruhan hasil validasi modul elektronik oleh dua validator memperoleh persentase $96,17 \%$ dengan kategori sangat valid.

\section{b. Praktikalitas Modul Elektronik}

Modul bertujuan untuk memberikan kemudahan bagi guru untuk mengajarkan materi menulis teks eksplanasi kepada siswa. Sejalan dengan itu, Kapitan et al., (2018) mengemukakan bahwa isi yang sederhana dan sistematis akan memudahkan guru dan siswa dalam mempraktikkan kegiatan pembelajaran dengan mudah. Modul pembelajaran menjadi solusi pembelajaran yang praktis terkait materi menulis teks eksplanasi.

Untuk memperoleh nilai kepraktisan modul elektronik, dilakukan penyebaran angket kepraktisan modul elektronik kepada guru dan siswa setelah melakukan pembelajaran menulis teks eksplanasi. Praktikalitas modul elektronik berguna untuk mengetahui apakah modul elektronik yang dirancang merupakan modul elektronik yang praktis digunakan oleh siswa. Angket kepraktisan berisi butir-butir pernyataan tentang kedua aspek kepraktisan modul elektronik tersebut. Butirbutir pernyataan tersebut dikembangkan dengan berpedoman pada indikator kepraktisan modul elektronik, yaitu kemudahan dalam penggunaan dan dapat dipelajari sesuai dengan waktu yang ditentukan. Angket praktikalitas guru terdiri atas 18 butir pernyataan dan untuk siswa terdiri atas 17 butir pernyataan.

Tabel 5. Deskripsi Data Praktikalitas Modul Elektronik oleh Guru

\begin{tabular}{llcccc}
\hline No. & Aspek Penilaian & $\begin{array}{c}\text { Jumlah } \\
\text { Skor }\end{array}$ & $\begin{array}{c}\text { Skor } \\
\text { Maksimal }\end{array}$ & $\begin{array}{c}\text { Nilai } \\
\text { Praktikalitas }\end{array}$ & Kategori \\
\hline 1. & Kemudahan penggunaan & 56 & 60 & $93,33 \%$ & Sangat Praktis \\
2. & Waktu yang digunakan & 10 & 12 & $83,33 \%$ & Sangat praktis \\
\hline $\begin{array}{l}\text { Praktikalitas E-Modul secara } \\
\text { Keseluruhan }\end{array}$ & $\mathbf{6 6}$ & $\mathbf{7 2}$ & $\mathbf{9 1 , 6 6 \%}$ & $\begin{array}{l}\text { Sangat } \\
\text { Praktis }\end{array}$ \\
\hline
\end{tabular}


Berdasarkan Tabel 5, hasil uji praktikalitas modul elektronik oleh guru, yaitu (1) kemudahan penggunaan memperoleh persentase 93,33\% dengan kategori sangat praktis, dan (2) waktu yang digunakan memperoleh persentase $83,33 \%$ dengan kategori sangat praktis. Jadi, secara keseluruhan hasil uji praktikalitas modul elektronik oleh guru memperoleh persentase $91,66 \%$ dengan kategori sangat praktis.

Tabel 6. Deskripsi Data Praktikalitas Modul Elektronik Siswa

\begin{tabular}{ccccc}
\hline No. & \multicolumn{1}{c}{ Aspek Penilaian } & Jumlah Skor & $\begin{array}{c}\text { Nilai } \\
\text { Praktikalitas }\end{array}$ & Kategori \\
\hline 1. & Kemudahan penggunaan & 1453 & $86,48 \%$ & Sangat praktis \\
2. & Waktu yang digunakan & 311 & $86,36 \%$ & Sangat praktis \\
\hline $\begin{array}{l}\text { Praktikalitas E-Modul secara } \\
\text { Keseluruhan }\end{array}$ & $\mathbf{1 7 6 4}$ & $\mathbf{8 6 , 3 8 \%}$ & Sangat praktis \\
\hline
\end{tabular}

Berdasarkan Tabel 6, hasil uji praktikalitas modul elektronik oleh siswa, yaitu (1) kemudahan penggunaan memperoleh persentase $86,48 \%$ dengan kategori sangat praktis, dan (2) waktu yang digunakan memperoleh persentase $86,36 \%$ dengan kategori sangat praktis. Jadi, secara keseluruhan hasil uji praktikalitas modul elektronik oleh siswa memperoleh persentase $86,38 \%$ dengan kategori sangat praktis.

\section{c. Efektivitas Modul Elektronik}

Keefektifan siswa mencapai sasaran belajar ditentukan oleh tiap-tiap individu. Artinya, hasil belajar siswa menentukan keefektifan bahan ajar yang digunakan (Kemp, 1994, p. 320). Efektivitas modul elektronik diperoleh dari dua sumber, yaitu hasil tes kinerja menulis teks eksplanasi dan penilaian sikap. Kedua data tersebut dijabarkan sebagai berikut.

Pertama, hasil belajar siswa diperoleh melalui tes pengetahuan (kognitif) dan tes unjuk kerja (psikomotor). Hasil tes unjuk kerja menulis teks eksplanasi siswa merupakan salah satu acuan untuk menentukan efektivitas modul elektronik pembelajaran menulis teks eksplanasi berbantuan aplikasi Flipping Book PDF Professional siswa kelas XI PH 1 SMK Negeri 9 Padang. Data ini dikumpulkan pada pertemuan terakhir tahap uji coba produk. Setelah pembelajaran dengan modul elektronik selesai, kompetensi pengetahuan dan keterampilan siswa diuji dengan tes pengetahuan dan tes unjuk kerja menulis teks eksplanasi.

Tabel 7. Rekapitulasi Nilai Hasil Belajar Siswa

\begin{tabular}{clcccc}
\hline No. & Hasil Belajar & Jumlah Skor & Jumlah Nilai & Rata-rata & Predikat \\
\hline 1. & Tes Pengetahuan & 1305 & 2310 & 87 & $\mathrm{~A}$ \\
2. & Tes Keterampilan & 1694 & 2646,79 & 88,22 & $\mathrm{~A}$ \\
\hline
\end{tabular}

Berdasarkan Tabel 7, nilai hasil belajar siswa pada tes pengetahuan memperoleh rata-rata 87 dengan predikat $A$ dan pada tes keterampilan memperoleh rata-rata 88,22 dengan predikat $A$. Pada tes pengetahuan, siswa yang mendapatkan nilai A $(86-100)$ berjumlah 22 orang dan siswa yang mendapatkan B $(71-85)$ berjumlah 8 orang. Sedangkan pada tes keterampilan 
siswa yang mendapatkan nilai $A(86-100)$ berjumlah 20 orang dan siswa yang mendapatkan nilai B $(71-85)$ berjumlah 10 orang.

Kedua, penilaian sikap meliputi: (1) Saya menjawab salam ketika guru mengawali pembelajaran dengan berdoa; (2) Saya membangun konsep teks eksplanasi dengan pengetahuan saya sendiri dan mengerjakan latihan dengan sungguh-sungguh; (3) Saya menyelesaikan latihan dan tugas dengan tepat waktu; (4) Saya menulis teks eksplanasi sesuai dengan struktur teks yang benar; (5) Saya dan teman saling bekerja sama dan aktif dalam belajar; (6) Saya senang membantu teman yang belum mengerti dengan materi pelajaran; (7) Saya menghargai usaha saya sendiri dan bantuan teman; (8) Saya memahami perbedaan pendapat di antara teman-teman yang memberikan argumennya dalam berdiskusi; (9) Saya memotivasi teman untuk giat mempelajari teks eksplanasi; dan (10) Saya percaya diri dengan pencapaian usaha belajar saya untuk menghadapi tes pengetahuan dan keterampilan yang berkaitan dengan materi teks eksplanasi. Hasil penilaian sikap dapat dilihat pada Tabel 8.

\section{Tabel 8. Rekapitulasi Penilaian Sikap Siswa}

\begin{tabular}{|c|c|c|}
\hline Jumlah Skor & Rata-Rata & Predikat \\
\hline 2740 & 91,33 & A \\
\hline
\end{tabular}

Berdasarkan tabel di atas, hasil dari penilaian sikap siswa memperoleh ratarata $91,33 \%$ dengan predikat $A$. Siswa yang memperoleh nilai A (86-100) berjumlah 22 orang dan siswa yang memperoleh nilai $B(71-85)$ berjumlah 8 orang.

\section{Penutup}

Berdasarkan hasil penelitian dan pengembangan, diperoleh kesimpulan dari pengembangan produk modul elektronik berbantuan aplikasi Flipping Book PDF Professional pembelajaran menulis teks eksplanasi SMK Negeri 9 Padang sebagai berikut. Pertama, produk modul elektronik berbantuan aplikasi Flipping Book PDF Professional pembelajaran menulis teks eksplanasi SMK Negeri 9 Padang disajikan dalam bentuk tautan (link) yang dapat digunakan sebagai sumber belajar secara mandiri ataupun belajar di kelas. Modul elektronik ini dilengkapi dengan desain yang sangat menarik berupa teks, gambar, video pembelajaran, animasi, dan menggunakan warna yang indah untuk siswa kelas XI SMK. Kedua, produk modul elektronik berbantuan aplikasi Flipping Book PDF Professional pembelajaran menulis teks eksplanasi SMK Negeri 9 Padang ini menghasilkan data yang valid dari validator dengan rata-rata 96,17\%. Ketiga, produk modul elektronik berbantuan aplikasi Flipping Book PDF Professional pembelajaran menulis teks eksplanasi SMK Negeri 9 Padang ini dinilai sangat praktis dengan rata-rata dari guru $91,66 \%$ dan dari siswa $86,38 \%$. Keempat, produk modul elektronik berbantuan aplikasi Flipping Book PDF Professional pembelajaran menulis teks eksplanasi SMK Negeri 9 Padang ini dapat meningkatkan nilai hasil belajar siswa. Pada tes pengetahuan mendapatkan ratarata $87 \%$, sedangkan pada tes keterampilan mendapatkan rata-rata $88,22 \%$. 
Selain itu, penilaian sikap siswa ketika belajar menggunakan modul elektronik berbantuan aplikasi Flipping Book PDF Professional pembelajaran menulis teks eksplanasi SMK Negeri 9 Padang mendapatkan rata-rata 91,33\%.

\section{Daftar Pustaka}

Andi, P. (2011). Panduan Kreatif Membuat Bahan Ajar Inovatif. Yogyakarta: Diva Press.

Asmi, A. R., Surbakti B., A. N. D., \& Hudaidah C. (2018). Pengembangan EModul Berbasis Flip Book Maker Materi Pendidikan Karakter untuk Pembelajaran Mata Kuliah Pancasila MPK Universitas Sriwijaya. Jurnal Pendidikan IImu Sosial, 27(1), 1-10. https://doi.org/10.17509/jpis.v27i1.9395

Emzir. (2010). Metodologi Penelitian Kualitatif Analisis Data. Jakarta: Raja Grafindo Persada.

Hasanah. (2015). Pengembangan Bahan Ajar Membaca Cerpen Siswa Kelas XII IPA 1 SMAN 1 Ketapang. Nosi, 3(2), 202-211.

Jones, T., \& Brown, C. (2011). Reading Engagement: A Comparison Between EBooks and Traditional Print Books in an Elementary Classroom. International Journal of Instruction, 4(2), 5-22. https://www.eiji.net/dosyalar/iji_2011_2_1.pdf

Kapitan, Y. J., Harsiati, T., \& Basuki, I. A. (2018). Pengembangan Bahan Ajar Menulis Teks Cerita Fantasi Bermuatan Nilai Pendidikan Karakter di Kelas VII. Jurnal Pendidikan: Teori, Penelitian, Dan Pengembangan, 3(1), 100106. http://dx.doi.org/10.17977/jptpp.v3i1.10378

Kemp, J. (1994). Design Effective Instruction. Macmillan College: Publishing Company.

Krisnayuni, K., Darmawiguna, I. G. M., \& Putrama, I. M. (2015). Pengembangan E-Modul Berbasis Model Project Based Learning untuk Mata Pelajaran Video Editing (Studi Kasus: Kelas XI di SMK Negeri 1 Sukasada). KARMAPATI (Kumpulan Artikel Mahasiswa Pendidikan Teknik Informatika), 4(5), 472-480. https://doi.org/10.37058/jspendidikan.v3i1.193

Kurniawan, D., \& Dewi, S. V. (2017). Pengembangan Perangkat Pembelajaran dengan Media Screencastomatic Mata Kuliah Kalkulus 2 Menggunakan Model 4-D Thiagarajan. Jurnal Siliwangi: Seri Pendidikan, 3(1), 214-219.

Lasmiyati, L., \& Harta, I. (2014). Pengembangan Modul Pembelajaran untuk Meningkatkan Pemahaman Konsep dan Minat SMP. Pythagoras: Jurnal Pendidikan Matematika, http://dx.doi.org/10.21831/pg.v9i2.9077

9(2), 161-174.

Lin, J.-W., \& Lin, H.-C. K. (2019). User Acceptance in a Computer-Supported Collaborative Learning (CSCL) Environment with Social Network Awareness (SNA) Support. Australasian Journal of Educational Technology, 35(1), 1-12. https://doi.org/10.14742/ajet.3395

Mouri, K., Uosaki, N., \& Ogata, H. (2018). Learning Analytics for Supporting Seamless Language Learning using E-Book with Ubiquitous Learning System. Journal of Educational Technology \& Society, 21(2), 150-163. 
http://www.jstor.org/stable/26388390

Munthe, E. A., Silaban, S., \& Muchtar, Z. (2019). Discovery Learning Based EModule on Protein Material Development. Advances in Social Science, Education and Humanities Research, 384, 604-607. https://www.atlantispress.com/proceedings/aisteel-19/125928461

Nisa, H. A., Mujib, M., \& Putra, R. W. Y. (2020). Efektivitas E-Modul dengan Flip PDF Professional Berbasis Gamifikasi terhadap Siswa SMP. Jurnal Pendidikan Matematika Raflesia, 5(2), 13-25. https://doi.org/10.33449/jpmr.v5i2.11406

Noor, A. M., Embong, A. M., \& Abdullah, M. (2012). E-Books in Malaysian Primary Schools: the Terengganu Chapter. International Journal of Social, Behavioral, Educational, Economic, Business and Industrial Engineering, 6(6), 1106-1109. https://publications.waset.org/14320/pdf

Oktavia, A. S. (2021). Pengembangan E-Modul Bahasa Indonesia Berbasis Web di SMK Negeri 2 Wajo. Tesis Program Magister Pendidikan Bahasa Indonesia Universitas Negeri Makassar. http://eprints.unm.ac.id/19603/

Priatna, I. K., Putrama, I. M., \& Divayana, D. G. H. (2017). Pengembangan EModul Berbasis Model Pembelajaran Project Based Learning pada Mata Pelajaran Videografi untuk Siswa Kelas X Desain Komunikasi Visual di SMK Negeri 1 Sukasada. Jurnal Nasional Pendidikan Teknik Informatika, 6(1), 70-78. http://dx.doi.org/10.23887/janapati.v6i1.9931

Priyatni, E. T. (2014). Desain pembelajaran bahasa Indonesia dalam kurikulum 2013. Jakarta: Bumi Aksara.

Purwaningtyas, P., Dwiyogo, W. D., \& Hariyadi, I. (2017). Pengembangan Modul Elektronik Mata Pelajaran Pendidikan Jasmani, Olahraga, dan Kesehatan Kelas XI Berbasis Online dengan Program Edmodo. Jurnal Pendidikan: Teori, Penelitian, dan Pengembangan, 2(1), 121-129. http://dx.doi.org/10.17977/jp.v2i1.8471

Putra, I. K. R. A., Artawan, G., \& Putrayasa, I. B. (2014). Pengembangan Bahan Ajar Bahasa Indonesia pada Topik Teks Laporan Observasi Berbasis Tri Hita karana untuk Siswa Kelas VII SMP Negeri 1 Gianyar Bali. Jurnal Pendidikan dan Pembelajaran Bahasa Indonesia, 3(1), 1-10. https://ejournal-

pasca.undiksha.ac.id/index.php/jurnal_bahasa/article/view/1433

Rahmah, S. A., \& Widyartono, D. (2021). Pengembangan Modul Elektronik Menulis Teks Tanggapan Berbasis LMS Moodle dengan Muatan Ekoliterasi untuk Kelas 9. Diglosia: Jurnal Kajian Bahasa, Sastra, Dan Pengajarannya, 4(4), 473-486. https://doi.org/10.30872/diglosia.v4i4.259

Riduwan, M. B. A. D. (2012). Skala Pengukuran Variabel-Variabel Penelitian. Bandung: Alfabeta.

Sadiman, A. S., Rahardjo, R., \& Haryono, A. (2014). Media Pendidikan: Pengertian, Pengembangan dan Pemanfaatannya. Depok: PT. Raja Grafindo Persada.

Searmadi, B. P. H. (2016). Penerapan Inovasi Flipbook sebagai Media Pembelajaran untuk Meningkatkan Hasil Belajar Pengenalan PHP Kelas XI RPL di SMK Negeri 2 Mojokerto. IT-Edu: Jurnal Information Technology and 
Education, 1(2), 42-48. https://ejournal.unesa.ac.id/index.php/itedu/article/view/17547

Seruni, R., Munawaroh, S., Kurniadewi, F., \& Nurjayadi, M. (2019). Pengembangan Modul Elektronik Biokimia pada Materi Metabolisme Lipid Menggunakan Flip PDF Professional. Jurnal Tadris Kimiya, 4(1), 48-56. https://doi.org/10.15575/jtk.v4i1.4672

Sirikham, A., \& Sae-Ear, Y. (2014). The Development of Low Cost Electronic Books for the Blind. International Journal of Information and Education Technology, 4(4), 332. http://www.ijiet.org/show-47-470-1.html

Sugianto, D., Abdullah, A. G., Elvyanti, S., \& Muladi, Y. (2013). Modul Virtual: Multimedia Flipbook Dasar Teknik Digital. Invotec, 9(2), 101-116. https://doi.org/10.17509/invotec.v9i2.4860

Sugiyono, D. (2010). Metode Penelitian Kuantitatif dan R\&D. Bandung: Alfabeta. Suyoso, S., \& Nurohman, S. (2014). Pengembangan Modul Elektronik Berbasis Web sebagai Media Pembelajaran Fisika. Jurnal Kependidikan: Penelitian Inovasi Pembelajaran, 44(1), 73-82. https://doi.org/10.21831/jk.v44i1.2193

Trianto. (2012). Mendesain Model Pembelajaran Inovatif Progesif. Jakarta: Kencana.

Waluyo, B. (2014). Bahasa dan Sastra Indonesia untuk Kelas VII SMP dan MTs. Solo: Tiga Serangkai Pustaka Mandiri.

Watin, E., \& Kustijono, R. (2017). Efektivitas Penggunaan E-Book dengan Flip PDF Professional untuk Melatihkan Keterampilan Proses Sains. Prosiding Seminar Nasional Fisika (SNF), 1, 124-129. https://fisika.fmipa.unesa.ac.id/proceedings/index.php/snf/article/view/25

Yulianti, D. (2017). Problem Based Learning Model used to Scientific Approach Based Worksheet for Physics to Develop Senior High School Students Characters. Journal of Physics: Conference Series, 824(1), 12009. https://doi.org/10.1088/1742-6596/824/1/012009

Yuswanti, T. U. (2020). Pengembangan Modul Elektronik Menggunakan Sigil Materi Teks Eksplanasi untuk Siswa Kelas XI di SMK Brantas Karangkates. Jurnal Universitas Islam Malang, 8(1), 1-12. http://www.riset.unisma.ac.id/index.php/NOSI/article/view/5810/0 